\title{
Determination of Hazards and Risks in a Solar Power Plant Using the Matrix Risk Analysis
}

\author{
Berna Gür ${ }^{*}$, Şenol Yavuz ${ }^{2}$, Ahmet Doğan Çakır ${ }^{3}$ Dursun Ali Köse ${ }^{4}$ \\ ${ }^{1 *}$ Hitit University, European Journal of Science and Technology, Department of Property Protection and Security, Çorum, Turkey, (ORCID: 0000-0002-0674-4612), \\ bernagur@hitit.edu.tr \\ ${ }^{2}$ Hitit University, Osmancık Ömer Derindere Vocational School, Department of Property Protection and Security, Çorum, Turkey, (ORCID: 0000-0001-6261-9296), \\ senolyavuz@hitit.edu.tr. \\ ${ }^{3}$ Hitit University, Hitit Vocational School of Technical Sciences, Department of Property Protection and Security, Corum, Turkey, (ORCID: 0000-0002-2233-5069), \\ ahmetdogancakir@hitit.edu.tr \\ ${ }^{4}$ Hitit University, , Faculty of Science, Department of Chemistry, Çorum, Turkey, (ORCID: 0000-0003-4767-6799), dalikose@hitit.edu.tr,
}

(First received 16 February 2021 and in final form 5 April 2021)

(DOI: $10.31590 /$ ejosat.881614)

ATIF/REFERENCE: Gür, B, Yavuz, Ş., Çakır, A. D. \& Köse, D. A. (2021). Determination of Hazards and Risks in a Solar Power Plant Using the Matrix Risk Analysis. European Journal of Science and Technology, (23), 497-511.

\begin{abstract}
Electric power generation from renewable energy sources such as solar energy, wind energy and geothermal energy is an alternative option to energy generation from fosil flues. Renewable energy sources are more advantageous when we consider the environmental damage caused by fossil flues during energy generation. Our country is rich in terms of renewable energy resources with its location. When we consider the daily sunshine duration and the wind force in the flat plains, the number of power plants that generate electrical energy without harming the environment with solar panels and wind turbines is increasing day by day. In this study , as a result of field observations of a power plant that converts solar energy into electrical energy with solar panels in Çorum by instructors who have class B OHS certificate and field experince, the risk score was calculated by determining the hazards and risks by 5x5 L-type Matrix Risk analysis which is a qualitative risk assessment. According to the calculated risk score, twenty-four risks which include four high level risks, fifteen medium-level risks, and five low-level risks were identified and recommendations were made. We think that this study will make a positive contribution to the power plants to be established and to the actively onoing plants in terms of occupational health and safety.
\end{abstract}

Keywords: Solar energy, Occupational health and safety, Risk analysis, Matrix Method

\section{Güneş Enerjisi Santralinde Matris Risk Analiz Yöntemiyle Tehlike ve Risklerin Belirlenmesi}

$\ddot{O} z$

Güneş enerjisi, rüzgâr enerjisi ve jeotermal enerji gibi yenilene bilinir enerji kaynaklarından elektrik enerjisi üretimi fosil yakıtlardan enerji üretimine alternatif seçenek olmaktadır. Fosil yakıtların enerji üretimi sırasında çevreye verdiği zararları dikkate aldığımızda yenilenebilir enerji kaynakları daha avantajlıdır. Ülkemiz sahip olduğu konumu ile yenilenebilir enerji kaynakları bakımından zengindir. Günlük güneşlenme süresi ve düzlük ovalardaki rüzgâr şiddetini dikkate aldığımızda güneş panelleri ve rüzgâr gülleri ile çevreye zarar vermeden elektrik enerjisi üreten santrallerin her geçen gün sayısı artmaktadır. Bu çalışmada, B sınıfı İSG belgesine sahip, saha tecrübesi olan öğretim elemanları tarafından Çorum ilinde güneş panelleriyle güneş enerjisini elektrik enerjisine çeviren bir santralin saha gözlemleri sonucu, tehlike ve riskler kalitatif bir risk değerlendirmesi olan 5x5 L tipi Matris Risk analizi ile belirlenerek risk skoru hesaplanmıştır. Hesaplanan risk skoruna göre dört tane yüksek düzeyde risk, on beş tane orta düzeyde risk ve beş tane düşük düzeyde risk olmak üzere yirmi dört tane risk tespit edilerek önerilerde bulunulmuştur. Yapılan bu çalışma ile bundan sonraki kurulacak santrallere ve aktif olarak devam eden santrallere iş sağlığı ve güvenliği yönünden olumlu katkı sağlayacağını düşünmekteyiz.

Anahtar Kelimeler: Güneş enerjisi, İş sağlığı ve güvenliği, Risk analizi, Matris Yöntemi

*Corresponding Author: bernagur@hitit.edu.tr 


\section{Introduction}

Solar energy is one of the world's renewable energy sources, alternative to fossil fuels and not harming nature in terms of waste. The occurrence of formations in nature, the flow of matter and energy are due to solar energy $[1,2]$. Due to the location of our country, solar energy potential is high. Therefore, energy generation plants consisting of solar panels have been established in many of our provinces to generate electrical energy from solar energy [3].

It is very important to examine the hazards and risks caused by dangerous movement and situations in terms of occupational health and safety by using the heat and light effect of the Sun instead of manpower in solar energy plants where have very little human factors. It may be possible to prevent work accidents and occupational diseases as a result of identifying the existing hazards and risks with proactive approaches. Hazard is defined as the potential for harm of anything. This potential could be a situation or a behavior. Risk, on the other hand, refers to the probability of events such as death, injury, and loss of limb that may occur as a result of an event $[4,5]$.

The aim of occupational health and safety services is to adopt proactive approaches against work accidents and occupational diseases by providing a healthy and safe work environment for employees. Preventing work accidents and occupational diseases is possible with regulatory preventive measures by identifying hazards and risks as a result of risk assessment in workplaces[6].

According to the Occupational Health and Safety Law No.6331, employer / employer representatives are obliged to make a risk assessment or have them done in order to ensure the health and safety of their employees and the continuity of production in the workplace. With risk assessment, it will be possible to prevent work accidents and occupational diseases, and if they cannot be prevented, to reduce their rate $[5,7]$.

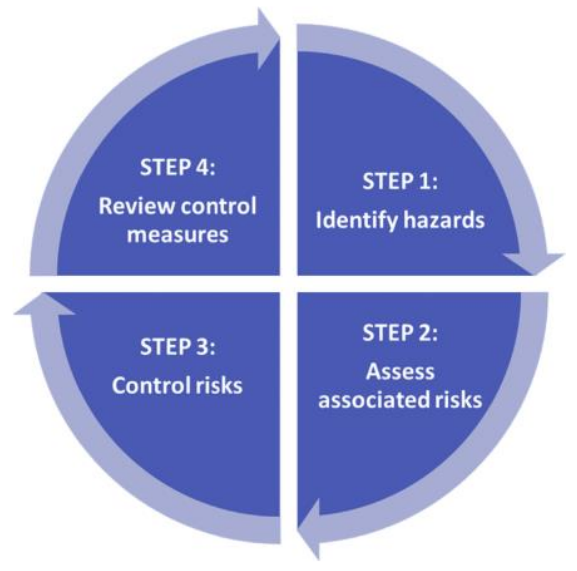

Fig. Risk Assessment Process Stages

During the identification of hazards and risks of a business , risk assessment is divided into two in terms of quality and quantity [8]. In the risk assessment application, a change is observed from qualitative approaches to semi-quantitative and traditional quantitative approaches [9]. According to Altenbach (1995), there are differences in the way of implementing risk assessment due to various reasons such as manpower, time, management perception, opinion of the OHS expert, applicability and understandability [10].
In the literature, risk analysis methods are divided into three groups as numerical (quantitative), verbal (qualitative) and mixed. Mathematical theorems are used when calculating the risk score with quantitative risk analysis, while performing qualitative risk analysis, the probability of occurrence of the threat and its potential effect in case of existence are calculated and the results obtained are processed with mathematical and logical methods and the risk score and degree are obtained [11]. Some of the risk analysis methods in the literature are classified as follows by dividing them into two groups as qualitatively and quantitatively[12],

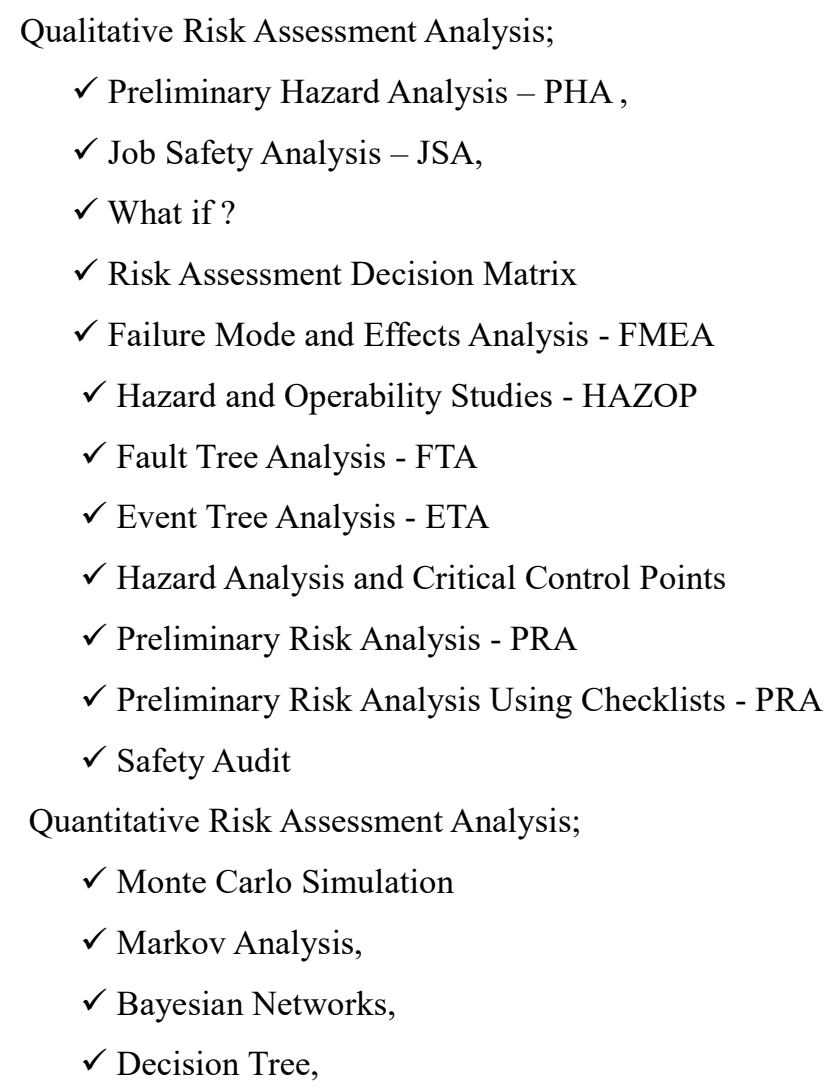

Occupational health and safety experts in our country use qualitative 5x5 Matrix and Finney-Kinney Risk analysis in identifying hazards and risks, calculating the risk score and categorizing the results, creating regulatory and preventive action plans [14].

\subsubsection{Matris Risk Analysis}

Although the matrix risk analysis X-Matrix is shown in $5 \times 5$ Matrix and L-Matrix shapes, it is the same in logic. It occurs only when the difference is calculated with $5 \times 5$ and the results are shown different in shape [13-14]. Matrix risk analysis is a method used to explain the relationship between two or more variables. It is an easier method in terms of being understandable and evaluating the results by the risk assessment team [15].

\subsubsection{L-Type Matris Risk Analysis}

It is a simple understandable method used in interpreting cause and effect relationship [16]. L matrix is implemented as $3 *$ $3,4 * 4,5 * 5$. It is a method based on evaluating the data obtained as a result of multiplying probability and severity each other which are the concrete components of risk analysis, within a logical framework. In this method, probability and severity factors are taken into account while the risk score is calculated. 
It is calculated as Risk Value $(\mathrm{R})=$ Probability $=(\mathrm{P}) \quad \mathrm{X}$ Severity (degree of damage).

Probability, the state that a danger occurs in a timeframe; violence, on the other hand, is defined as the degree of damage to the workplace if danger occurs [15-18].

Table 1. L-Type Matrix Analysis Probability Table

\begin{tabular}{|c|c|c|}
\hline Value & Categorization & Frequency \\
\hline $\mathbf{1}$ & Very low & Once a year \\
\hline $\mathbf{2}$ & Low & Once every three months \\
\hline $\mathbf{3}$ & Medium & Once a months \\
\hline $\mathbf{4}$ & High & Once a week \\
\hline $\mathbf{5}$ & Very high & Every day \\
\hline
\end{tabular}

Table 2. L-Type Matrix Analysis Loss Level Table

\begin{tabular}{|c|c|c|}
\hline Value & Result & Rating \\
\hline $\mathbf{1}$ & Insignificant & $\begin{array}{c}\text { No loss of working hour } \\
\text { requiring first-aid }\end{array}$ \\
\hline $\mathbf{2}$ & Minor & $\begin{array}{c}\text { No loss of working day, requiring } \\
\text { first-aid }\end{array}$ \\
\hline $\mathbf{3}$ & Moderate & Mild injury requires treatment \\
\hline $\mathbf{4}$ & Major & $\begin{array}{c}\text { Death, Serious injury, } \\
\text { occupational disease }\end{array}$ \\
\hline $\mathbf{5}$ & Catastrophic & $\begin{array}{r}\text { Multiple deaths, permanent } \\
\text { incapacity }\end{array}$ \\
\hline
\end{tabular}

\subsubsection{Type Matrix Risk Analysis}

It is a risk analysis that requires a disciplined work done as a team with the establishment of a risk team. L type matrix and $\mathrm{X}$ type matrix risk analysis are similar.There is only a difference in
Tablo 3. L-Type Risk Score Rating Matrix

\begin{tabular}{|c|c|c|c|c|c|c|}
\hline \multicolumn{7}{|c|}{ Result (Severity) } \\
\hline \multirow{2}{*}{\multicolumn{2}{|c|}{$\begin{array}{c}\text { Probabilit } \\
\mathbf{y}\end{array}$}} & 5 & 4 & 3 & 2 & 1 \\
\hline & & $\begin{array}{l}\text { Criti } \\
\text { cal }\end{array}$ & Severe & $\begin{array}{l}\text { Moder } \\
\text { ate }\end{array}$ & Minor & $\begin{array}{l}\text { Negligi } \\
\text { ble }\end{array}$ \\
\hline 5 & $\begin{array}{l}\text { Very } \\
\text { High }\end{array}$ & 25 & 20 & 15 & 10 & 5 \\
\hline 4 & High & 20 & 16 & 12 & 8 & 4 \\
\hline 3 & $\begin{array}{l}\text { Medi } \\
\text { um }\end{array}$ & 15 & 12 & 9 & 6 & 3 \\
\hline 2 & Low & 10 & 8 & 6 & 4 & 2 \\
\hline 1 & $\begin{array}{l}\text { Very } \\
\text { Low }\end{array}$ & 5 & 4 & 3 & 2 & 1 \\
\hline
\end{tabular}

1-2 Points: Insignificant risk. Risks that do not matter much and can be accepted.

3-6 Points: Tolerable risk. It is a tolerable risk group that requires attention in the long term.

8-12Points: Moderate risk. They are significant risks that need to be taken measures in the short term.

15-16 Points: Significant risk. It is the risk group that is extremely important and should be taken measures immediately

20-25 Points: Not tolerable risk. It is the risk group that it is not accepted to start work without any measures.

The fields shown with red color in the risk matrix indicate unacceptable risks and mean that measures must be taken as soon as possible. The fields shown in yellow express risks that need to be fixed as soon as possible. The fields shown in green express nonurgent risks that need to be fixed in the long term.

shape. The most preferred in practice is $5 \times 5$ Risk Matrix Analysis. The risk score is the same in both methods, but the order and shape are different from each other.

Tablo 4. A Sample Risk Assessment Analysis

\begin{tabular}{|c|c|c|c|c|c|c|c|c|c|c|c|c|c|c|c|}
\hline \multirow{2}{*}{ 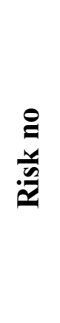 } & \multirow{2}{*}{ 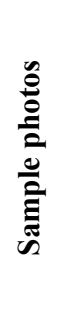 } & \multirow{2}{*}{ 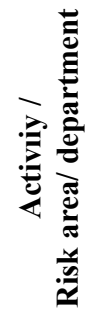 } & \multirow{2}{*}{ 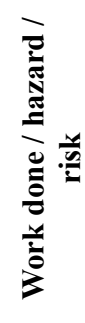 } & \multirow{2}{*}{ 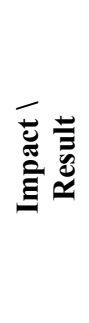 } & \multicolumn{2}{|c|}{ 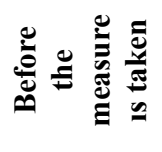 } & \multicolumn{2}{|c|}{ 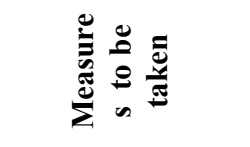 } & \multirow[t]{2}{*}{ 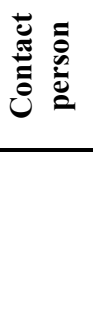 } & \multirow[t]{2}{*}{ 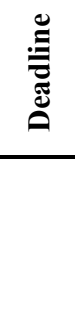 } & \multirow[t]{2}{*}{ 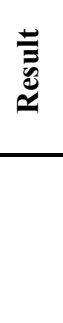 } & \multirow[t]{2}{*}{ 竎 } & \multicolumn{3}{|c|}{ 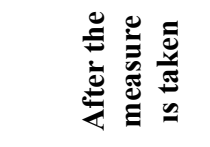 } \\
\hline & & & & & $\mathbf{P}$ & $\mathbf{S}$ & 䆓 & & & & & & $\mathbf{P}$ & $\mathbf{S}$ & 䆓 \\
\hline 1 & & 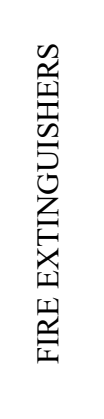 & 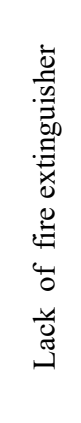 & 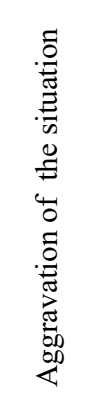 & 4 & 5 & 20 & 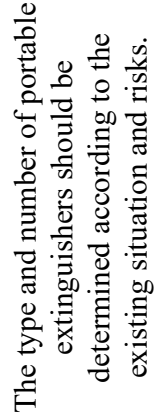 & 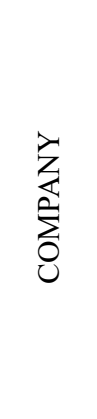 & 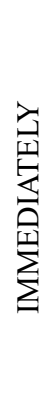 & & & 1 & 5 & 5 \\
\hline
\end{tabular}


Table 5.Risk Score Calculation Table

\subsection{Fine Kinney Risk Analysis}

It is one of the risk analysis methods used in occupational health and safety. Although it is a bit more complicated than the matrix risk analysis, it is a more ordered risk analysis in terms of separating the business lines from each other by frequency factor. It was first put forward by Fine in 1971, and then, in 1976, Fine's proposal was developed by Kinney and Wiruth and became a risk analysis method [19]. It was first used to protect against explosives in the military field, and then became the most preferred risk analysis method in dangerous and very dangerous enterprises such as construction and mining when it began to be used in the OHS profession.[19-20].

Although Fine Kinney Risk Analysis is more complex than Matrix risk analysis, it has higher accuracy and frequency factor. In this analysis method, the risk score is obtained by multiplying three variables, namely probability $(\mathrm{P}), \quad$ severity $(\mathrm{S})$ and frequency $(\mathrm{F})$.

\begin{tabular}{|l|l|}
\hline \multirow{4}{*}{ RISK=PXSXF } & R: Size of the Risk \\
\cline { 2 - 3 } & $\begin{array}{l}\text { P: Possibility of Hazard Occurrence } \\
\text { S: Potential Violent Damage of the } \\
\text { Hazard }\end{array}$ \\
\cline { 2 - 3 } & F: frequency of repetition of work \\
\hline
\end{tabular}

Tablo 6. Probability Value Chart

\begin{tabular}{|c|l|c|}
\hline $\begin{array}{c}\text { Probability } \\
\text { Value }\end{array}$ & \multicolumn{1}{c|}{ Definition } & $\begin{array}{c}\text { \% } \\
\text { Probability }\end{array}$ \\
\hline 10 & Expected / Certain & 50 \\
\hline 6 & High / Quite Possible & 10 \\
\hline 3 & Possible & 1 \\
\hline 1 & Rarely but Possible & $10-3$ \\
\hline 0,5 & Unexpected but Possible & $10-4$ \\
\hline 0,2 & Practically Not Possible & $10-5$ \\
\hline 0,1 & Only Theoretically Possible & $10-6$ \\
\hline
\end{tabular}

Table 7. Severity value definition table

\begin{tabular}{|c|c|c|}
\hline \multirow{3}{*}{ S Value } & \multicolumn{2}{|c|}{$\begin{array}{c}\text { Severity - Scoring The Damage / Element (V) } \\
\text { (Estimated damage to human and / or environment) }\end{array}$} \\
\hline & \multicolumn{2}{|l|}{ Definition } \\
\hline & Loss of work & Material loss \\
\hline 100 & Multiple fatal accidents environmental disaster & $>10.000 .000$ \\
\hline 40 & Fatal accident / Serious environmental damage & $1.000 .000-10.000 .000$ \\
\hline 15 & Permanent damage / injury, loss of work & $100.000-1.000 .000$ \\
\hline 7 & $\begin{array}{l}\text { Creating environmental barriers, significant damage / injury from the } \\
\text { immediate environment, getting external first aid }\end{array}$ & $10.000-100.000$ \\
\hline 3 & $\begin{array}{l}\text { Minor damage, injury, internal first aid, limited environmental damage } \\
\text { on land }\end{array}$ & $1.000-10.000$ \\
\hline 1 & Escape with littlle or no harm / no environmental damage & $100-1.000$ \\
\hline
\end{tabular}

Table 8. Frequency value definition table

\begin{tabular}{|c|c|}
\hline \multicolumn{2}{|c|}{ Frequency Scoring (F) } \\
\hline F Value & Definition \\
\hline 10 & Almost continuously (several times in an hour) \\
\hline 6 & Frequently (once or several times a day) \\
\hline 3 & Occasionally (once or several times a week) \\
\hline 2 & Not often (once or several times a month) \\
\hline 1 & Rarely (several times a year) \\
\hline 0,5 & Hardly ever (once a year or less) \\
\hline
\end{tabular}


European Journal of Science and Technology

\begin{tabular}{|c|c|l|l|}
\hline \multicolumn{5}{|c|}{ Risk Identification } \\
\hline Risk Rating & R Value & \multicolumn{1}{|c|}{ Risk Class } & \multicolumn{1}{|c|}{ What to Do } \\
\hline 1 & $\mathrm{R} \leq 20$ & Minor risk & Precaution is not a priority \\
\hline 2 & $20<\mathrm{R} \leq 70$ & Acceptable risk & Should be applied under observation \\
\hline 3 & $70<\mathrm{R} \leq 200$ & Moderate risk & Should be improved in the long term \\
\hline 4 & $200<\mathrm{R} \leq 400$ & Significant risk & $\begin{array}{l}\text { Should be improved in the short term } \\
\text { (within a few months) }\end{array}$ \\
\hline 5 & $\mathrm{R}>400$ & Unacceptable risk & $\begin{array}{l}\text { Necessary precautions should be taken } \\
\text { immediately or the facility, building, } \\
\text { production or its surroundings should be } \\
\text { closed. }\end{array}$ \\
\hline
\end{tabular}

\section{Material And Method}

This study was made as a result of the field observations of OHS experts who have Class B occupational safety certificates in the profession of occupational health and safety of a power plant consisting of solar panels where manpower is not used. It is a study that consists of calculating the risk scores of the hazards and risks identified as a result of the observations using the $5 \times 5$ Matrix qualitative risk analysis method and recommending regulatory preventive actions. Calculation method for 5x5 Matrix Risk score analysis is as follows

Tablo 10. Risk Score Calculation Table

\begin{tabular}{|c|c|c||c|c|c||}
\hline \multicolumn{5}{|c||}{ Risk Factor Calculatıon System: The one with a higher risk parameter will be taken. } \\
\hline \hline \multicolumn{2}{|c|}{ Probability (Exposure-Incident frequency) } & \multicolumn{3}{c||}{ Severity (Possible Losses) } \\
\hline \hline Parameter & Probability & $\begin{array}{c}\text { Occurrence } \\
\text { Frequency }\end{array}$ & Parameter & Severity & Rating \\
(For Human)
\end{tabular}


Tablo 11. Risk Score Definition Table

\begin{tabular}{|c|c|c|c|c|c|}
\hline Risk Score & \multicolumn{5}{|c|}{ Severity } \\
\hline \multirow{2}{*}{ Probability } & $\mathbf{1}$ (Negligible) & $\mathbf{2}$ (Minor) & $\mathbf{3}$ (Moderate) & $\mathbf{4}$ (Severe) & $\mathbf{5}$ (Critical) \\
\hline \multirow{2}{*}{1 (Very low) } & Meaningless & Low & Low & Low & Low \\
& 1 & 2 & 3 & 4 & 5 \\
\hline \multirow{2}{*}{2 (Low) } & Low & Low & Low & Medium & Medium \\
& 2 & 4 & 6 & 10 \\
\hline \multirow{2}{*}{3 (Medium) } & Low & Low & Medium & Medium & High \\
& 3 & Medium & Medium & High & Very High \\
\hline \multirow{2}{*}{4 (High) } & Low & 8 & 12 & 16 & 20 \\
\hline \multirow{2}{*}{5 (Very high) } & 4 & Medium & High & Very high & Not tolerable \\
& 5 & 10 & 15 & 20 & 25 \\
\hline
\end{tabular}

Table 12. Acceptability Values of Results and Order of Priority

\begin{tabular}{|c|l|}
\hline $\begin{array}{c}\text { Unbearable Risks } \\
(20,25) \text {-Priority } 1\end{array}$ & $\begin{array}{l}\text { The work should not be started until identified risk is reduced to an acceptable level, } \\
\text { and if there is an ongoing action, it should be stopped immediately. If it is not possible } \\
\text { to reduce the risk in despite of the measures taken, the action should be prevented. }\end{array}$ \\
\hline Significant Risks & $\begin{array}{l}\text { The work should not be started until the identified risk is reduced, if there is an } \\
\text { ongoing action, it should be stopped immediately. If the risk is related to the } \\
\text { continuation of the work, urgent measures should be taken and as a result of these } \\
\text { measures, it should be decided to continue the action. }\end{array}$ \\
\hline Moderate Risks & $\begin{array}{l}\text { Actions should be started to reduce the identified risks. Risk reduction measures can } \\
\text { take time. }\end{array}$ \\
\hline Tolerable Risks & $\begin{array}{l}\text { Additional control processes may not be needed to eliminate identified risks. However, } \\
\text { existing controls should be continued and it should be checked that these controls are } \\
\text { continued. }\end{array}$ \\
\hline Minor Risks & $\begin{array}{l}\text { It may not be necessary to plan control processes and keep records of actions to be } \\
\text { carried out to eliminate identified risks. }\end{array}$ \\
\hline
\end{tabular}

\section{Risk Score $=$ Probability X Severity}

In the light of the above data, the hazards and risks identified in the solar power plant, the regulatory and preventive actions to be taken and the risk score that can be reduced as a result of the actions are as follows. . There are no part-time or full-time employees in this solar power plant. Only technical personnel coming from outside can enter the power plant. The system is remotely controlled. 
European Journal of Science and Technology

Table 13.Acceptability Values of Results Matrix risk analysis data applied to the solar power plant

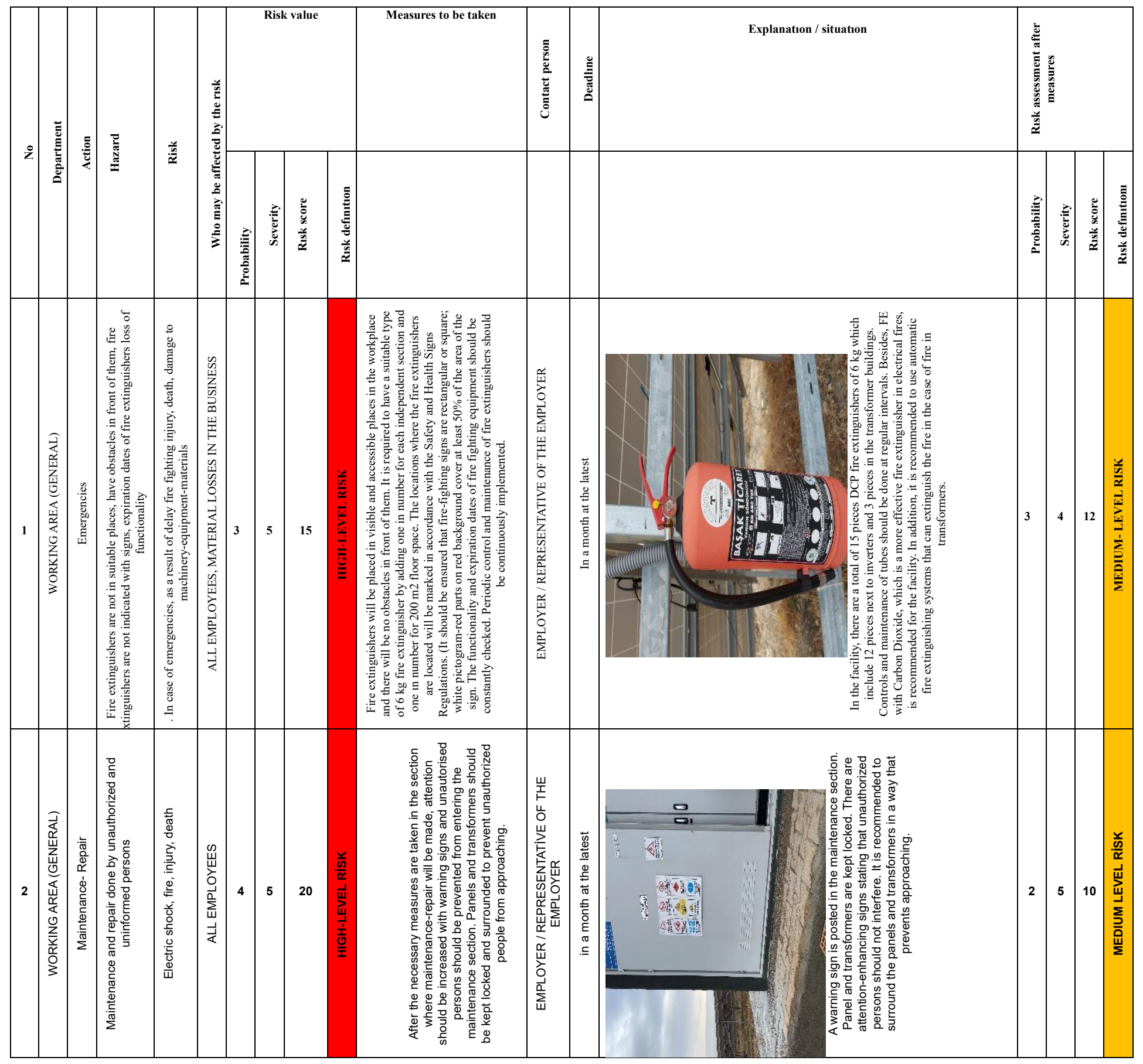




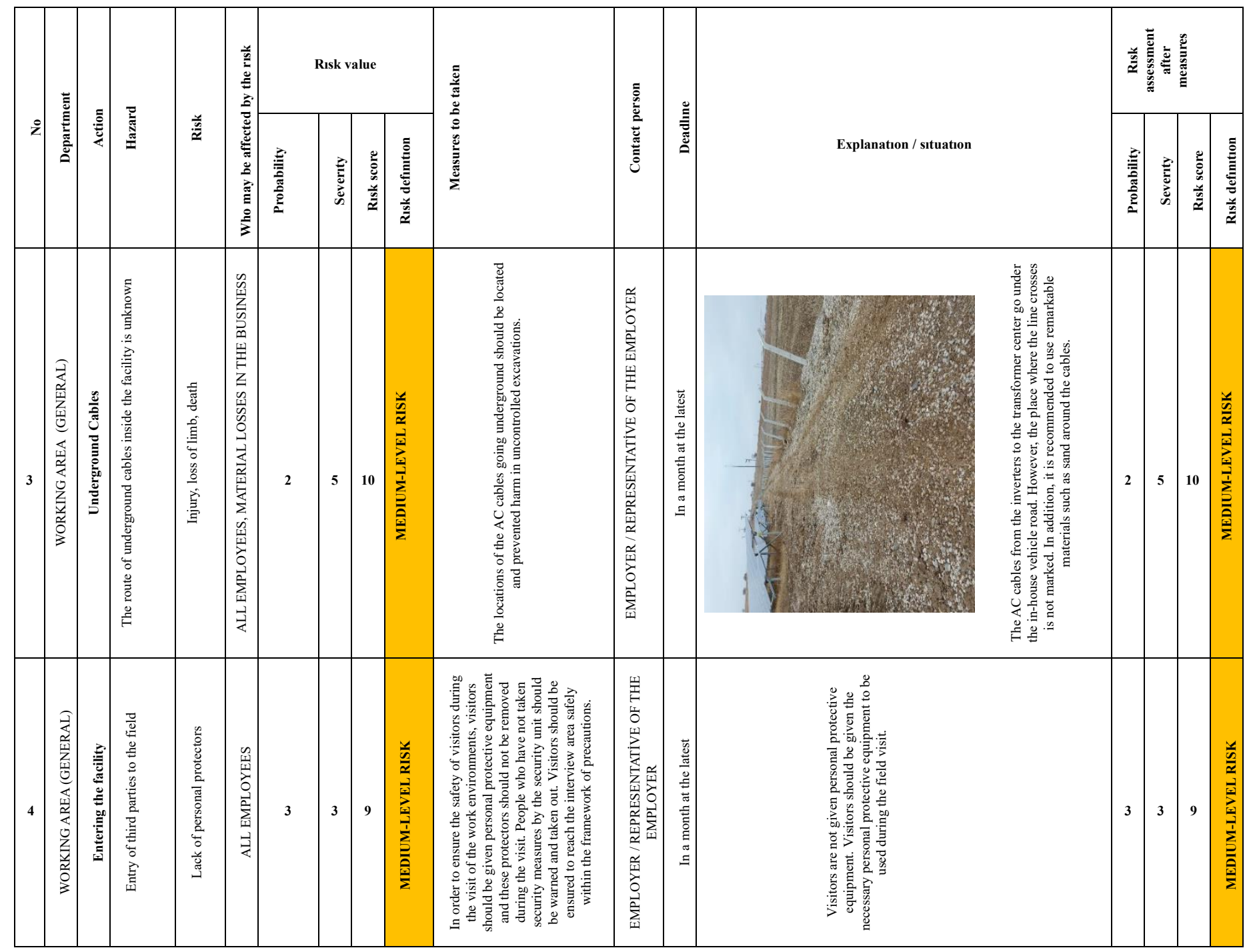

\begin{tabular}{|c|c|c|c|c|c|c|c|c|c|c|c|c|c|c|c|c|c|}
\hline \multirow[b]{2}{*}{$\stackrel{8}{2}$} & & \multirow[b]{2}{*}{$\frac{\bar{g}}{\frac{\delta}{4}}$} & \multirow[b]{2}{*}{ 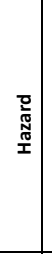 } & \multirow{2}{*}{\multicolumn{2}{|c|}{ 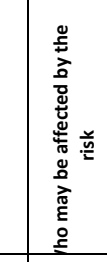 }} & \multicolumn{4}{|c|}{ Risk value } & \multirow[b]{2}{*}{ Measures to be taken } & \multirow[b]{2}{*}{ 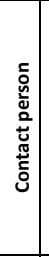 } & & \multirow[b]{2}{*}{ Explanation / situation } & \multicolumn{4}{|c|}{$\begin{array}{l}\text { Risk assessment after } \\
\text { measures }\end{array}$} \\
\hline & 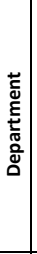 & & & & & 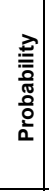 & 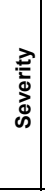 & 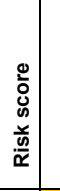 & 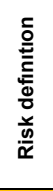 & & & 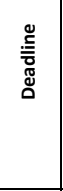 & & & 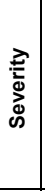 & 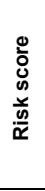 & 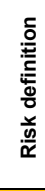 \\
\hline 5 & 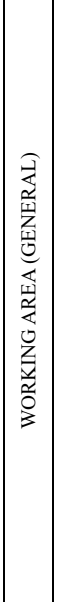 & 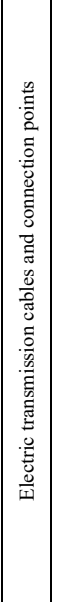 & 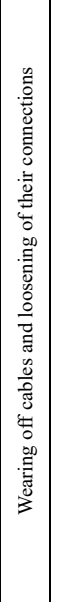 & 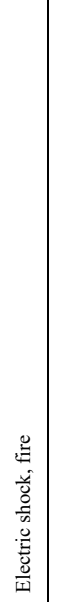 & 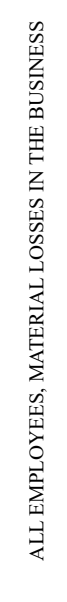 & 2 & 5 & 10 & 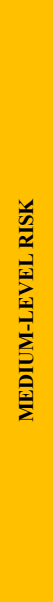 & 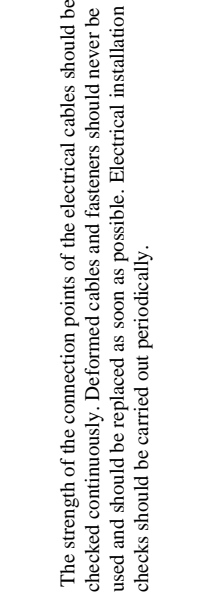 & 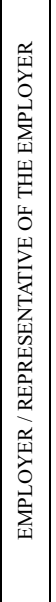 & 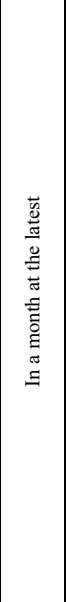 & & & 5 & 10 & 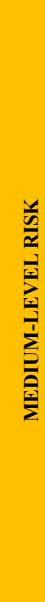 \\
\hline
\end{tabular}




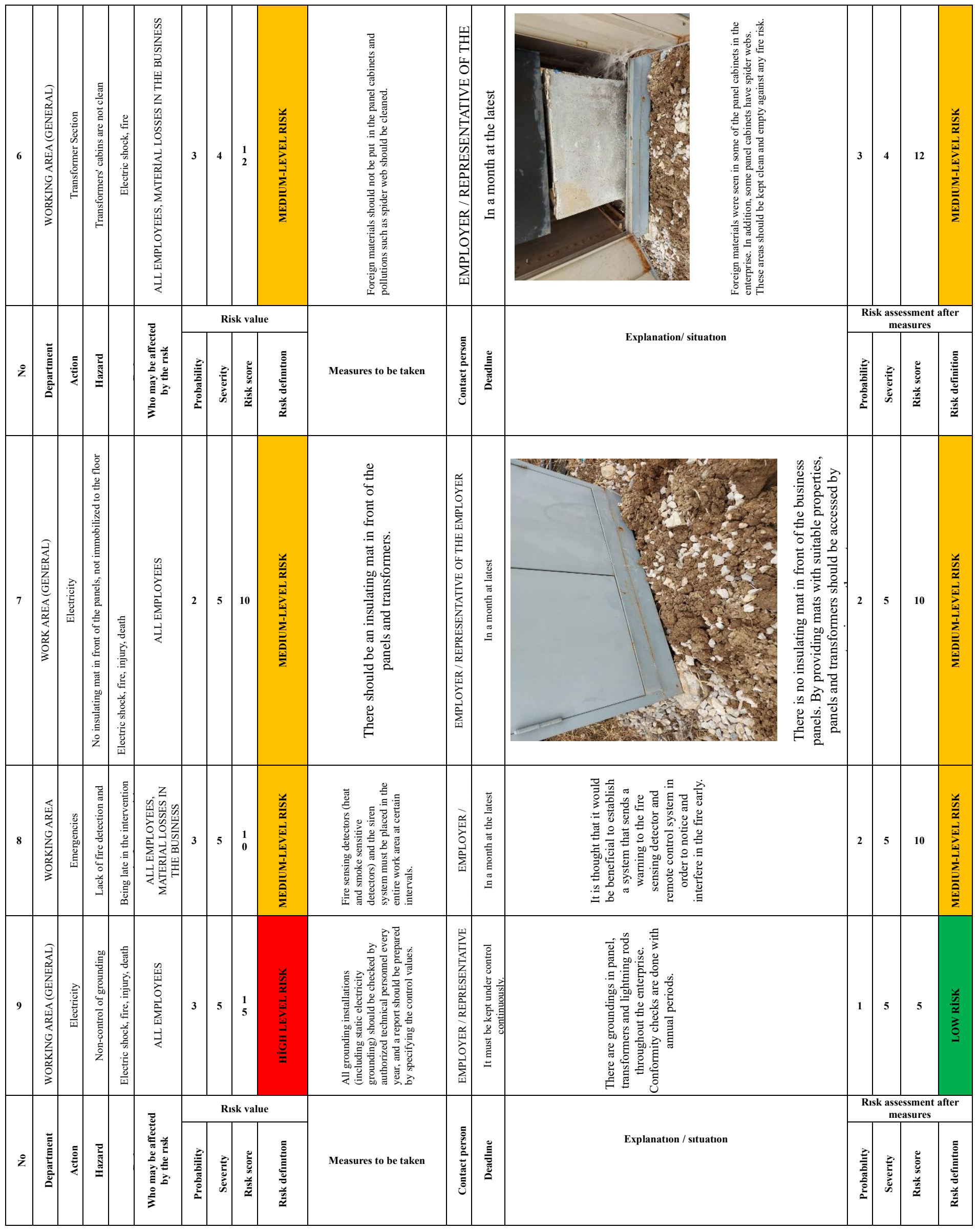




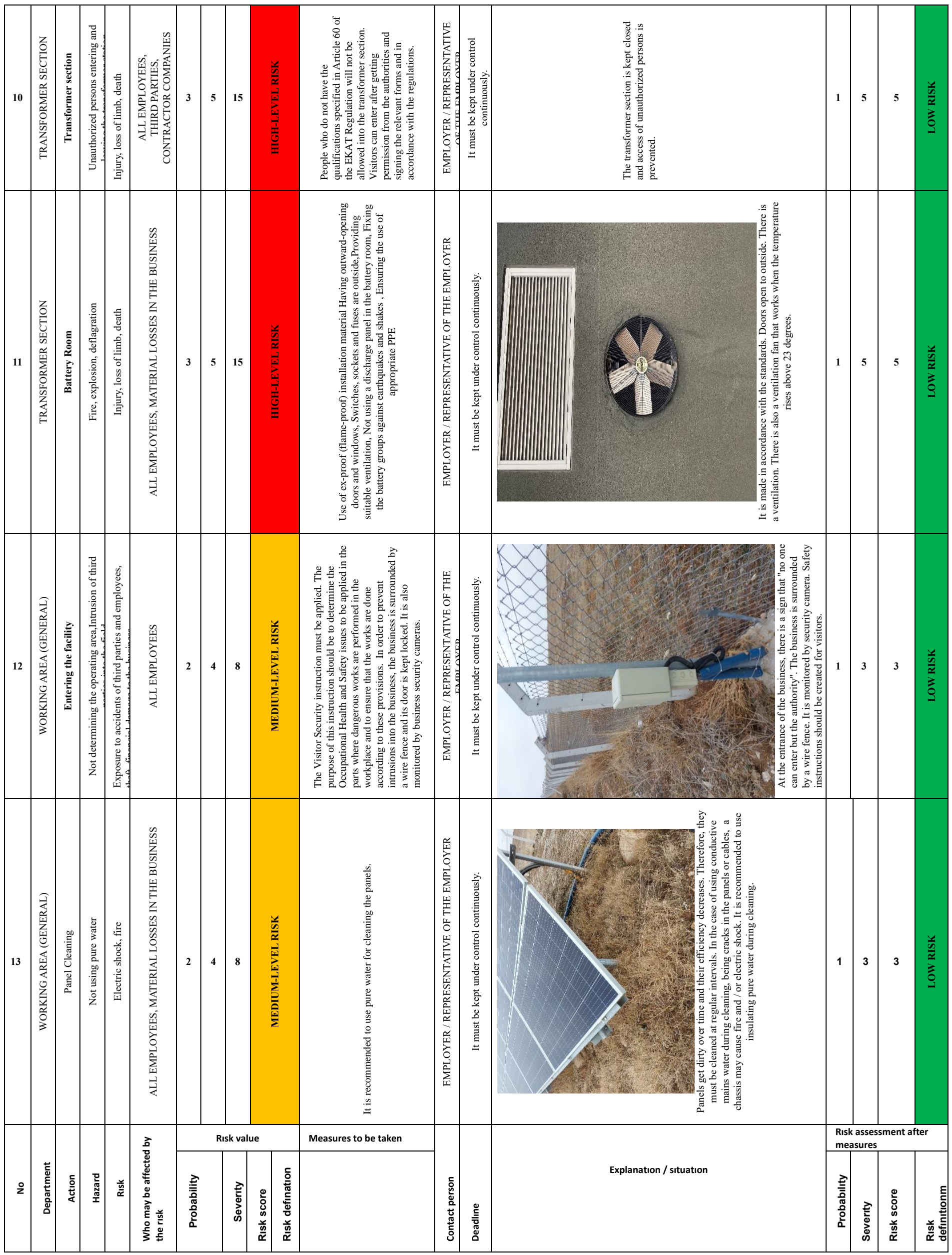




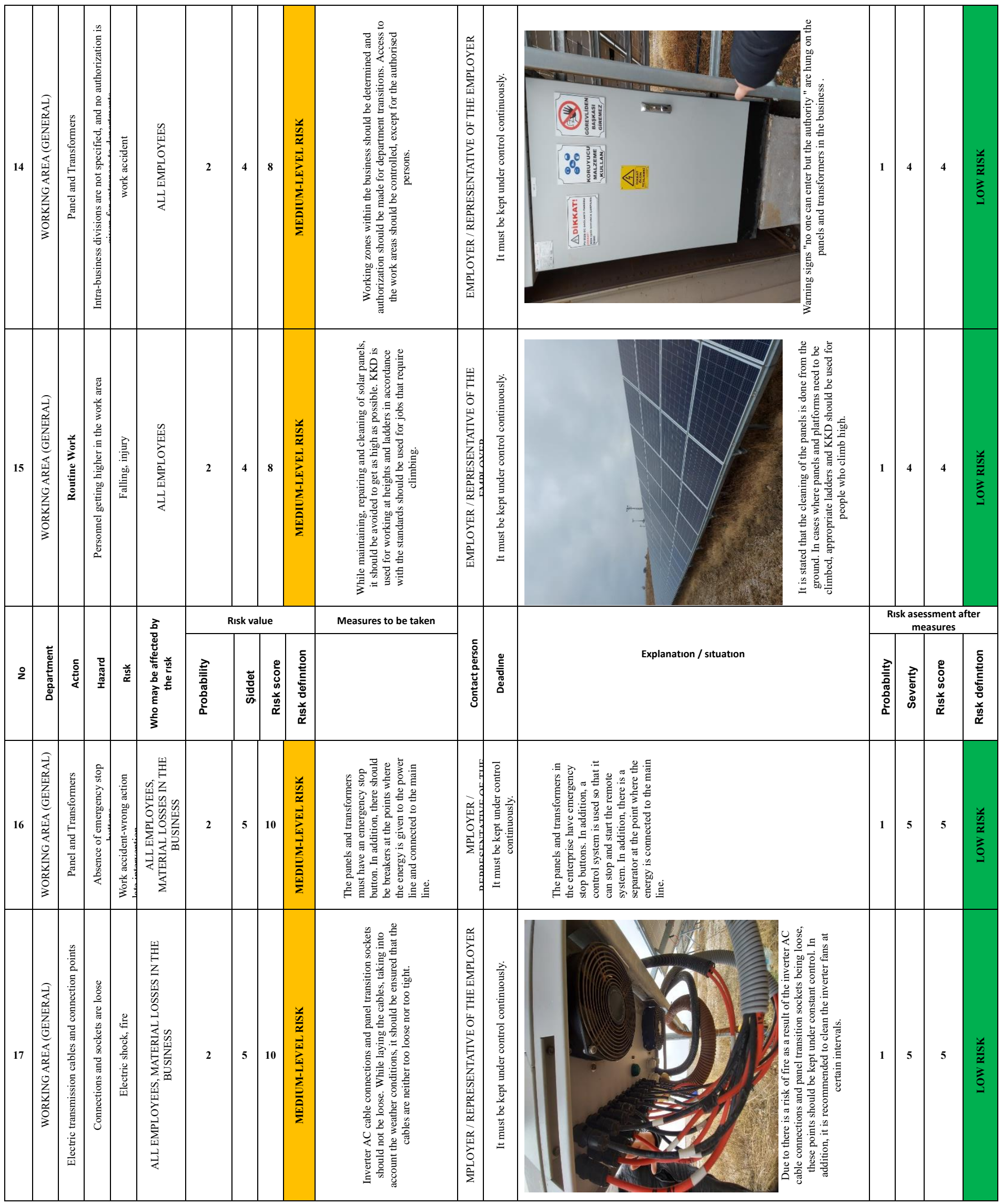




\begin{tabular}{|c|c|c|c|c|c|c|c|c|c|c|c|c|c|c|c|}
\hline 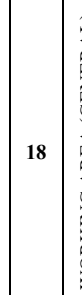 & 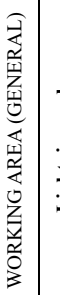 & 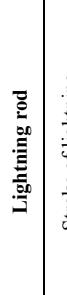 & 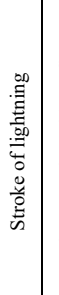 & 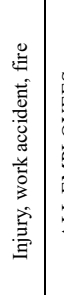 & 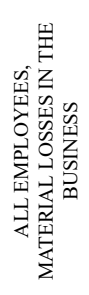 & 2 & 5 & 10 & 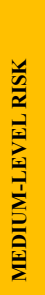 & 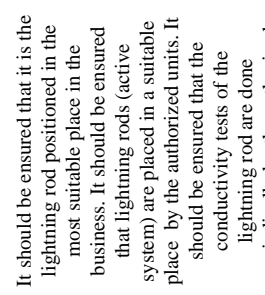 & 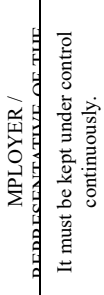 & 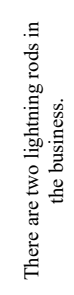 & 1 & 5 & 5 \\
\hline
\end{tabular}

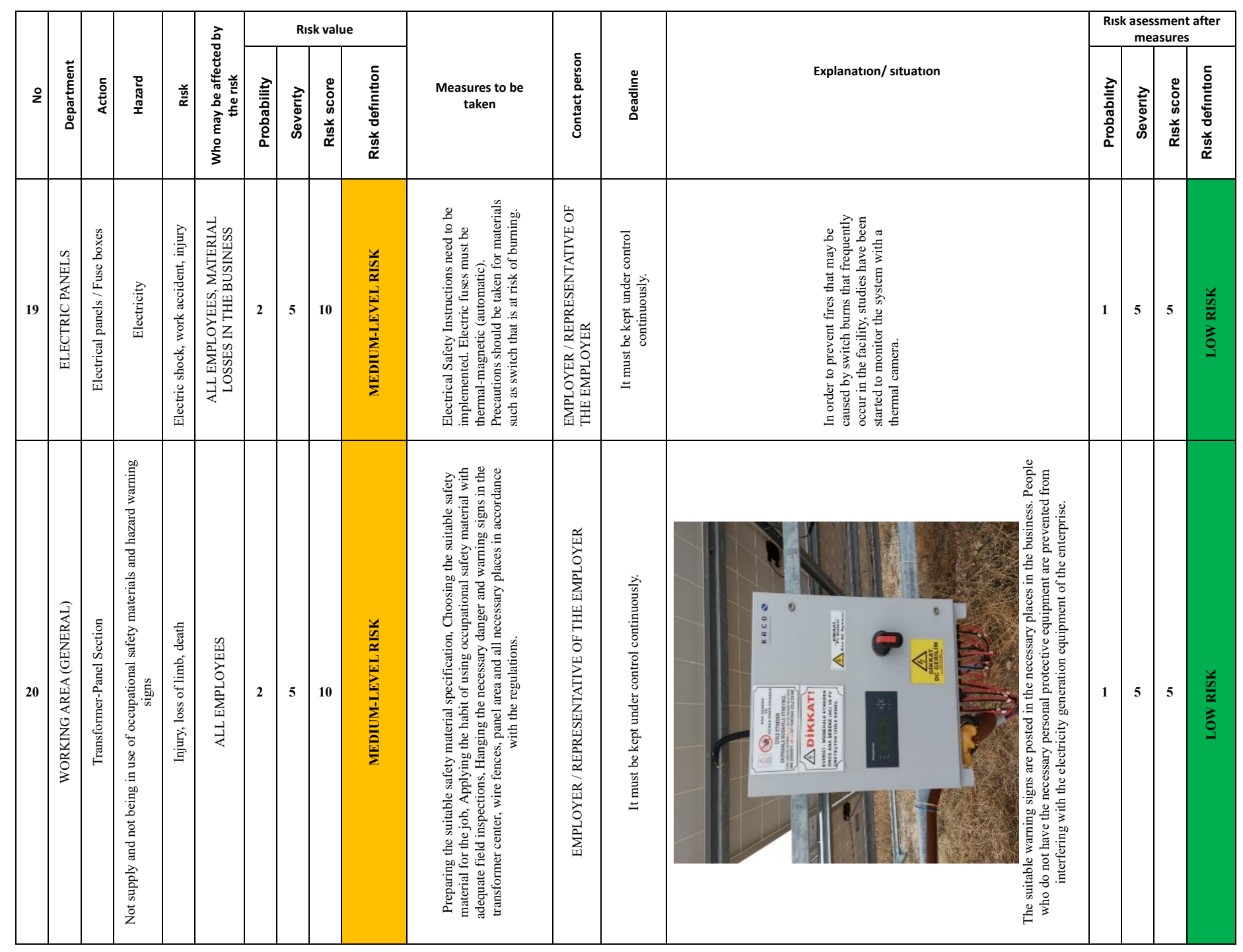

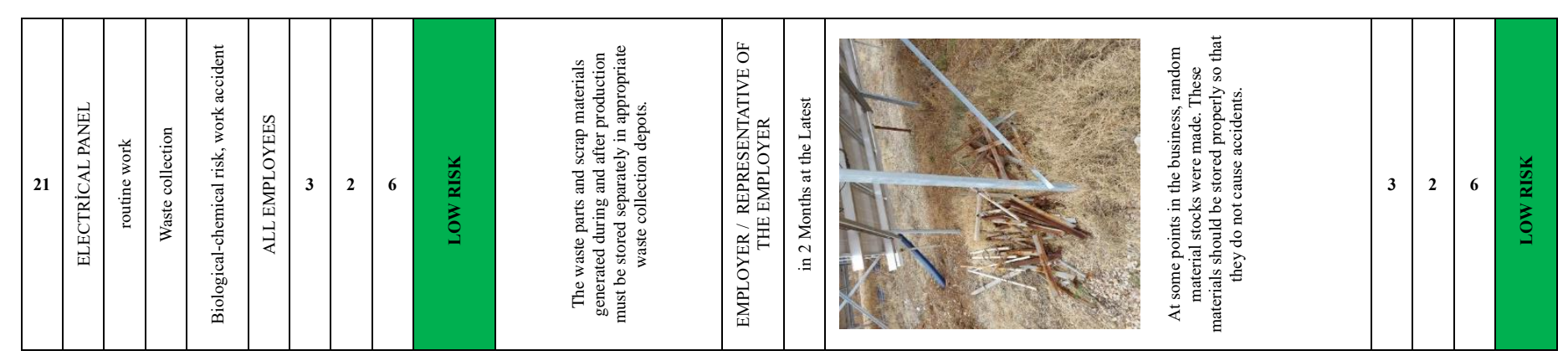




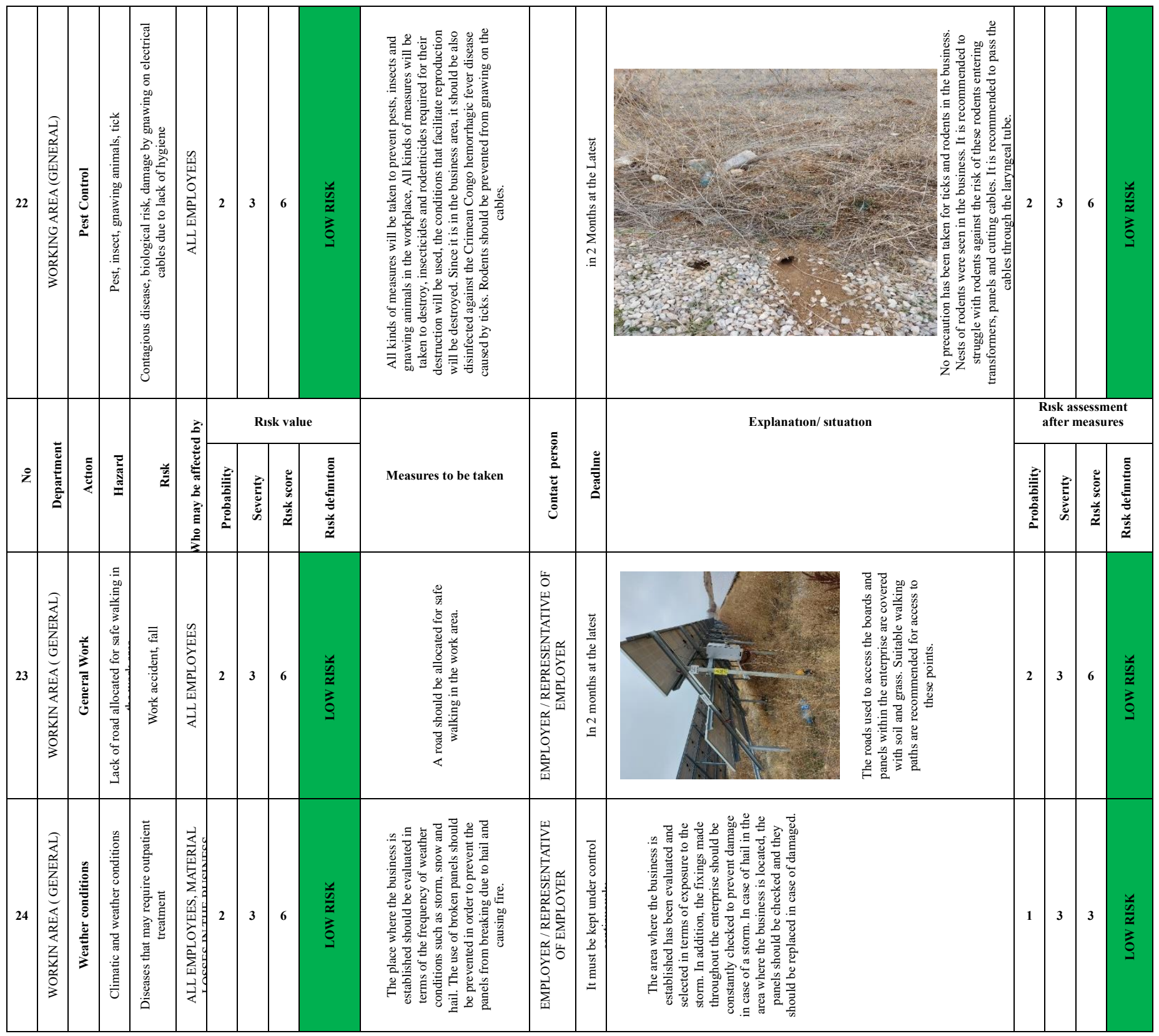

\begin{tabular}{|c|c|c|c|c|c|c|c|c|c|c|c|c|c|c|c|c|c|}
\hline \multirow[b]{2}{*}{$\stackrel{2}{2}$} & & & \multirow[b]{2}{*}{ 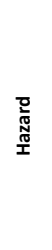 } & \multirow[b]{2}{*}{$\frac{\frac{2}{\alpha}}{\bar{\alpha}}$} & \multirow{2}{*}{ 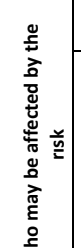 } & \multicolumn{4}{|c|}{ Risk value } & \multirow[b]{2}{*}{ Measures to be taken } & \multirow[b]{2}{*}{ 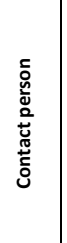 } & \multirow[b]{2}{*}{ 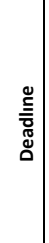 } & \multirow[b]{2}{*}{ Explanation / sttuation } & \multicolumn{4}{|c|}{$\begin{array}{c}\text { Risk assesment after } \\
\text { measures }\end{array}$} \\
\hline & 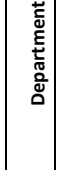 & $\frac{5}{\frac{5}{4}}$ & & & & 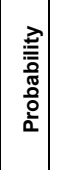 & 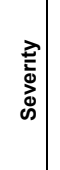 & 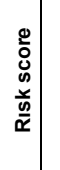 & 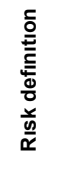 & & & & & 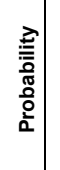 & , & 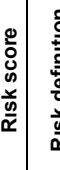 & 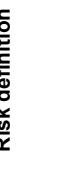 \\
\hline
\end{tabular}




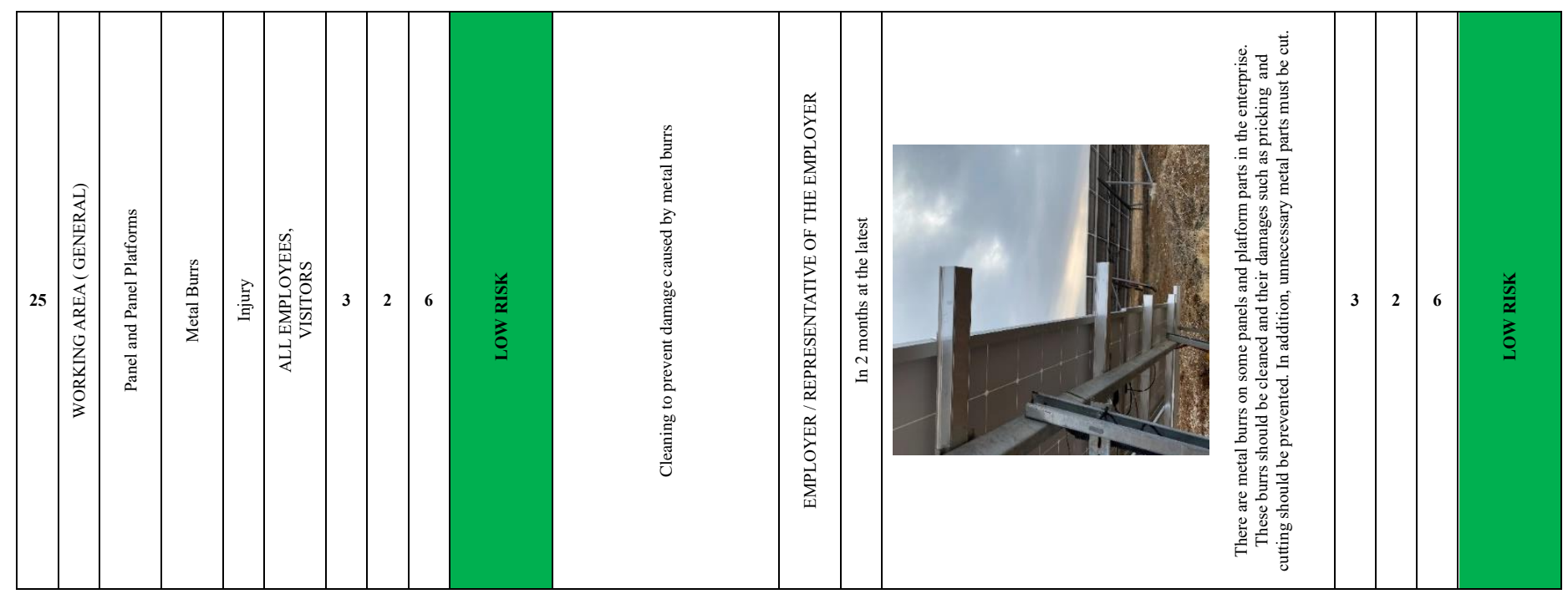

\section{Results And Discussion}

Due to its location, Turkey has high potential in terms of solar energy. Our country has an average of 7.5 hours of sunshine per day [21]. In the works done during the conversion of solar energy into electrical energy through energy panels, fixed electrical circuits and panels are used rather than manpower. There are no insured and full time employees. However, during the control of the system, the occupational safety of the technical staff who come to the power plant during outsourcing should be ensured in order to install new technological circuits and solve various problems caused by the environment.

Various hazards and risks are at stake during the installation of panels based on energy generation in the solar power plant, doing periodic controls and the installation of new panels by technical staff. These hazards and risks can be evaluated with a $5 \times 5$ L type Matrix risk analysis and work accidents and occupational diseases can be prevented by taking the necessary measures. The aim of occupational health and safety practices is to provide employees with a healthy and safe working environment by showing the necessary proactive approaches to work accidents and occupational diseases.

As a result of the $5 \times 5 \mathrm{~L}$ type Matrix risk analysis, high-level risks were shown as four and red, medium-level risks as fifteen and yellow, low-level risks as five and green. The probability score was calculated for the identified risks and the regulatory and preventive action was specified. Hazards such as the lack of location, number and control of fire tubes, unauthorized and uninformed persons coming to the power plant for technical support, not taking measures against the possibility of fire and explosion in the battery room, and lack of grounding installation that should be done once a year at the latest or not being checked constitute high -level risks. Regulatory measures should be taken in a short time.

Risks arising from dangerous movements and situations such as not showing the passage route of the cables in the ground inside the facility,the entrance of people from outside the power plant to the power plant,loosening, abrasion and breakage of the electrical transmission cables and connections, the transformer cabinets are not in compliance with hygiene rules, the lack of insulating mats in front of the panels, the lack of fire detection and siren system in emergency situations or not working, not using pure water during cleaning of solar panels, not taking the necessary measures when working at height in the power plant, the lack of emergency stop buttons and lightning rod are included in the medium-level risk group. Regulatory and preventive actions should be taken in the medium term to control these risks and prevent their harm.

Failure to store waste in the work area, to pest control and spraying, lack of a suitable walking corridor for employees and visitors in the work area, sunstroke in summer due to weather conditions, and lack of suitable place in case of cold and freezing in winter, damage caused by metal burrs in and around panel poles are defined as a low- level risk. Necessary measures should be taken in the long term.

Although the degree of risks identified may vary according to the prediction and interpretation of the observing occupational health and safety expert, the risk level remains the same. The necessary measures should be taken for identified risks and should be followed regularly. The risks identified in solar power plants are also close to each other in other solar and wind power plants. They are plants with low human factors. The risk analysis performed is a qualitative risk analysis. The response of the data obtained is expressed verbally as low, medium and high levels. In our country, occupational health and safety experts working actively in the field have difficulties in applying and interpreting Fine Kinney, which is not a quantitative analysis but a qualitative analysis. Therefore, 5x5 Matrix risk analysis is used to identify hazards and risks in the profession of occupational health and safety.

A study was done by Dündar and Ethem (2016) on the issues related to the measures to be taken in terms of occupational health and safety during the installation and field phase of solar power plants $[22,24]$. Çelik and Utku (2013) contributed to the literature on OHS in energy studies by working on the examination of possible situations to be experienced during the installation phase of the wind power plant in terms of occupational health and safety [23].

\section{Acknowledge}

I would like to thank Ahmet AKTAŞ, the owner of the solar power plant, and Asist.Prof.Dr. Berna GÜR and lecturer Ahmet Doğan ÇAKIR, who supported the preparation of the article. 


\section{References}

Külekçi, Ö. C. (2009). Yenilenebilir enerji kaynakları arasında jeotermal enerjinin yeri ve Türkiye açısından önemi. Ankara Üniversitesi Çevre Bilimleri Dergisi, 1(2), 83-91.

Varınca, K. B., ve Gönüllü, M. T. (2006). Türkiye'de güneş enerjisi potansiyeli ve bu potansiyelin kullanım derecesi, yöntemi ve yaygınlığı üzerine bir araştırma. I. Ulusal Güneş ve HidrojenEnerjisi Kongresi, 270-275.

Varınca, K. B., ve Varank, G. (2005). Güneş kaynaklı farklı enerji üretim sistemlerinde çevresel etkilerin kıyaslanması ve çözüm önerileri. Güneş Enerjisi Sistemleri Sempozyumu ve Sergisi, İçel, 24-25.

Samantra, C., Datta, S., Mahapatra, S.S., (2017). Analysis of occupational health hazards and associated risks in fuzzy environment: a case research in an Indian underground coal mine. Int. J. Inj. Contr. Saf. Promot. 24 (3), 311-327.

Gül, M., Ak, M. F.,(2018). A comparative outline for quantifying risk ratings in occupational health and safety risk assessment. Journal of Cleaner Production 196, 653-664.

Yavuz, Ş., Gür, B., Yavuz, A.(2020). İmalat işlerinde çalışanlarda iş sağlığı ve güvenliği algı düzeyinin incelenmesi, Journal of Social and Humanities Sciences Research, 7(59), 2618-2627.

Samantra, C., Datta, S., Mahapatra, S.S., (2017). Analysis of occupational health hazards and associated risks in fuzzy environment: a case research in an Indian underground coal mine. Int. J. Inj. Contr. Saf. Promot. 24 (3), 311-327.

Ilbahar, E., Karas, an, A., Cebi, S., Kahraman, C., (2018). A novel approach to risk assessment for occupational health and safety using Pythagorean fuzzy AHP \& fuzzy inference system. Saf. Sci. 103, 124-136.

Elmonstri, M.(2014). Review of the strengths and weaknesses of risk matrices, Journal of Risk Analysis and Crisis Response, Vol. 4, No. 1, 49-57.

Altenbach, T (1995). “A comparison of risk assessment Techniques from qualitative to quantitative", proceedings of the joint ASMEIJSME pressure vessels and piping conference, Honolulu HI.

Ekşioğlu, M. (2014). Türkiye'de iş sağlığı ve güvenliğinin genel durumu, öneriler ve sistem yaklaşımı. Ge-li-yo-rum Diyen Facia - Boğaziçi Üniversitesi Soma Araştırma Grubu Raporu, 167-181.

International Organization for Standardization. (2009). ISO 31000:2009 Risk Management - Principles and Guidelines on Implementation.
Tixier J., Dusserre G., Salvi O., Gaston D., (2002). Review of 62 Risk Analysis Methodologies of Industrial Plants, Journal of Loss Prevention in the Process Industries, 15(4), 291-303.

Şenol, M. Yılmaz, N. (2017). İş Sağlığı Ve Güvenliği Risk Değerlendirme Süreci İçin Bulanık Çok Kriterli Bir Model Ve Uygulaması. Gazi Üniversitesi Mühendislik Mimarlık Fakültesi Dergisi, 32 (1) , 0-0 . DOI: 10.17341/gazimmfd.30059

Ölçücü, H, Ersöz Kaya, İ. (2019). Tehlikeli Atık Bertaraf Tesislerinde Meslek Hastalığı ve Biyolojik Faktörler Açısından Risk Değerlendirmesi. Avrupa Bilim ve Teknoloji Dergisi , (17) , 1375-1382. DOI: 10.31590/ejosat.668653

Erten, B, Utlu, Z. (2017). İlaç lojistik sektöründe risk analizi yapılarak 5x5 Matris, Fine Kinney ve FMEA yöntemleri ile risk değerlendirmelerinin karşılaştırılması: bir firma örneği. Anadolu Bil Meslek Yüksekokulu Dergisi, 12 (48), 1-14. Retrieved from https://dergipark.org.tr/tr/pub/abmyoder/issue/55975/7 67522

Aytekin, O., Kaya, M. Ü., Kuşan, H. (2015) Yapı İşlerinde Proje Tipi Çalışma Verilerine Uygun İSG Risk Değerlendirme Yönteminin Seçimi İçin Öneriler. TMMOB İnşaat Mühendisleri Odası Bildiriler Kitabı. 127-136

Usanmaz, D. Köse, E. (2019). Karşılaştırmalı Risk Analizi Metotlarının Bir Araştırma Merkezi İçin Uygulanması ve Sonuçların Değerlendirilmesi, 2. International Mediterranean Symposium, 1, 140-158, Mersin, Türkiye.

Birgören, B. (2017) Fine Kinney Risk Analizi Yönteminde Risk Analizi Yönteminde Risk Faktörlerinin Hesaplama Zorlukları ve Çözüm Önerileri. Uluslararası Mühendislik Araştırma ve Geliştirme Dergisi. 9(1), 19-25.

Aytekin, O., Kaya, M. Ü., Kuşan, H. (2015) Yapı İşlerinde Proje Tipi Çalışma Verilerine Uygun İSG Risk Değerlendirme Yönteminin Seçimi İçin Öneriler. TMMOB İnşaat Mühendisleri Odası Bildiriler Kitabı. 127-136

Taktak, F, Ilı, M . (2018). Güneş Enerji Santrali (GES) Geliştirme: Uşak Örneği. Geomatik, 3 (1), 1-21. DOI: 10.29128/geomatik.329561

Dündar, U. Ertem, M. (2016) Güneş Enerjisi Santrallerinin Kurulumu İçin Risk Değerlendirme Rehberi. Ankara: TMMOB.

Çelik Ö., Utlu, Z. (2013). Rüzgâr Enerji Santrallerinde İş Sağlığı Ve Güvenliği Uygulamaları. İstanbul Aydın Üniversitesi Dergisi, Y1l; 5, Say1; 19, ss. 57/64.

Acar, B. Sönmez, İ. (2020). Güneş Enerji Santralleri Kurulum Aşamasında Alınacak Olan İş Sağlığı Ve Güvenliği Önlemleri. Doğu Fen Bilimleri Dergisi, 3 (2), 95-108 .https://dergipark.org.tr/tr/pub/dfbd/issue/56837/78281 